\title{
Upper Precambrian (Eocambrian) Mineral Fork Tillite of Utah: A continental glacial and glaciomarine sequence: Discussion and reply
}

\author{
Discussion
}

NICHOLAS CHRISTIE-BLICK Exxon Production Research Company, P.O. Box 2189, Houston Texas 77001

The observations and interpretation of the Mineral Fork Tillite by Ojakangas and Matsch (1980) are most welcome. I concur with them and others that the formation is glaciogenic. However, I suggest that polish and striations on the underlying unconformity for the most part are not due to Proterozoic glacial activity, and I propose modifications to their over-all interpretation of the sequence in the Mineral Fork area.

\section{GLACIATED PAVEMENT}

The demonstration that lineations are Proterozoic glacial striations requires (1) that the lineations are surficial and are not traces of bedding, fractures, or cleavage; and (2) that other mechanisms of abrasion (for example, Pleistocene glaciers or faulting) can be excluded. In Mill B, North Fork (Fig. 1, locality 1), some grooves on the unconformity beneath the Mineral Fork Formation seem to meet these criteria (Blick, p. 333). Mostly, however, the unconformity surface is degraded and does not preserve polish or striations, even if these once existed.

Ojakangas and Matsch (1980) observed "striated, grooved, and polished bedrock at several places" (my italics) beneath the Mineral Fork Formation north-northwest of Lake Blanche (Fig. 1). I followed this well-exposed contact for $4 \mathrm{~km}$ southeast of Big Cottonwood Canyon, looking for evidence of ancient glacial activity. I concluded, however, that some of the lineations I observed were slickensides and that Pleis-

The article discussed was published in the Bulletin, Part l, v. 91, p. 495-501. tocene glacial abrasion could not be "uled out for the remainder on the basis of their orientation (Fig. 1).

Locality 3 is particularly instructive. Here, the contact beneath the Mineral Fork Formation is a gently dipping fault (strike, $111^{\circ} ;$ dip, $8^{\circ} \mathrm{S}$ ), which offsets quartzite and argillite beds of the underlying Big Cottonwood Formation by a few metres. Srratigraphic separation is comparable to the local erosional relief on the unconformity. There is little or no associated gouge, mineralization, or brecciation. Yet polish and slickensides (trend, $244^{\circ}$ ) are well developed on a $20-\mathrm{m}^{2}$ exposure of the fault surface. The fine lineations barely visible in Figure 5 of Ojakangas and Matsch (1980) may similarly be slickensides. They are not convincing Proterozoic glacial striations because the polish is so well preserved, in contrast to the lack of polish at most exposures of the unconformity. The cautious interpretation of such equivocal features in terms of glacial processes should therefore be distinguished from other considerably clearer evidence of ancient glaciation in the Mineral Fork Formation (for example, dropstones and striated clasts).

\section{INTERPRETATION OF MINERAL FORK FORMATION}

Ojakangas and Matsch (1980) interpret the Mineral Fork Formation in the vicinity of Mineral Fork as a lower member of continental till and outwash, overlain by an upper member of glacio-marine sediment released from floating ice. They envision one major marine transgression resulting from slow but steady subsidence of the continental margin.
However, the interpretation of the lower part of the sequence as interstratified lodgement till, flow till and outwash does not require continental (subaerial) sedimentation (for example, Rust and Romanelli, 1975). Depending on ice thickness, the glacier could have been grounded as much as several hundred metres below sea level (Denton and others, 1971). Total subsidence may therefore have been considerably less than the thickness of the formation.

The Mineral Fork Formation was deposited in a platform region of the relative tectonic stability (Ojakangas and Matsch, 1980). Most of the upper ProterozoicLower Cambrian sequence, several thousand metres thick in the miogeocline to the west, is missing (Crittenden and others, 1971). Yet the maximum thickness of the Mineral Fork Formation ( $900 \mathrm{~m}$ according to Ojakangas and Matsch, 1980) is comparable to that of equivalent miogeoclinal glaciogenic beds. The platform subsidence rate may have been anomalously high during glaciation. Alternatively, perhaps the thickness of the Mineral Fork Formation was controlled more by the configuration of a.lready submerged pre-existing topography than by tectonic subsidence (Christie-Blick, 1980).

Ojakangas and Matsch (1980) interpret diamictite in the upper part of the formation as largely debris melted out from floating ice. Some detritus was undoubtedly rafted (for example, pods of grit or conglomerate in texturally heterogeneous tillite, and some isolated clasts in laminites). However, stratigraphic evidence suggests that much of the diamictite is flow tillite, and some may be lodgement tillite. Contacts between diamictite beds and underlying

Geological Society of America Bulletin, v. 93, p. 184-187, 1 fig., February 1982. 


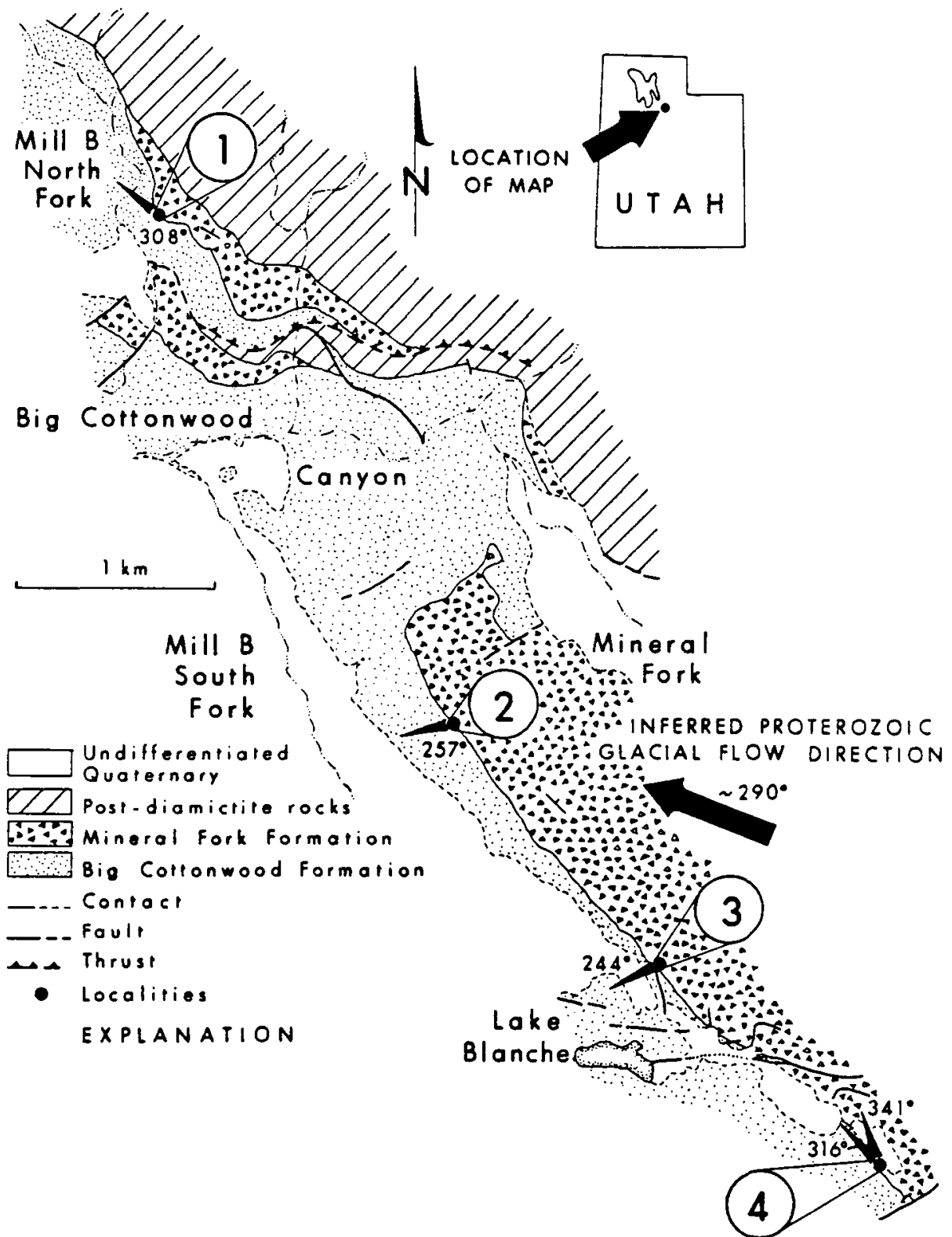

Figure 1. Examples of linear features of various origins on basal contact of Mineral Fork Formation in Mineral Fork area. Locality 1, Proterozoic(?) grooves on degraded surface of quartzite roche moutonnée(?) (trend $=307^{\circ}$, or $308^{\circ}$ after correction for tectonic tilt; Blick, 1979, p. 333). Locality 2, Proterozoic ridges (no polish; trend $=264^{\circ}$, or $257^{\circ}$ after correction for tectonic tilt). Locality 3 , slickensides on polished fault surface (trend $=244^{\circ}$ ). Locality 4, glacial striations of probable Pleistocene age (trend $=316^{\circ}, 341^{\circ}$ ). All trends given values between $180^{\circ}$ and $360^{\circ}$ for comparison because Proterozoic glacier or ice sheet inferred to have flowed toward $\sim 290^{\circ}$ (Blick, 1979).

laminated shale-siltstone units are generally sharp (Ojakangas and Matsch, 1980), and one contact (at the $750 \mathrm{~m}$ level in their Fig. 3) is locally erosional. The shale-siltstone, which occurs at several laterally continuous intervals as thick as $50 \mathrm{~m}$ and constitutes $15 \%$ to $25 \%$ of the formation, is virtually devoid of ice-rafted detritus (dropstones are very rare). If the associated diamictite, con-

channelized boulder conglomerate in the upper part of the sequence may be lodgement tillite. Because of petrologic differences, the conglomerate is unlikely to be a winnowing product of associated diamictite (Blick, 1979). As indicated by Ojakangas and Matsch (1980), boulders in the conglomerate could have been transported only by powerful currents, expected close to the glacier, but which would soon have dissipated in the sea after leaving tunnels in the ice. Diamictite overlying such conglomerate may therefore have been deposited from grounded ice.

Finally, the lithologic distinctions between the "upper" and "lower" members are not as clear as Ojakangas and Matsch (1980) imply. For example, whereas laminated shale-siltstone tends to occur preferentially in the upper part of the sequence in the Mineral Fork area, diamictite units are (with some exceptions) poorly stratified to massive throughout the formation. Furthermore, my mapping suggests that the thick sandstone unit, $450 \mathrm{~m}$ above the base in their lower (continental) member (their Fig. 3), is laterally equivalent immediately southward, and transverse to the glacial flow direction, to laminated shale-siltstone characteristic of their upper (marine) member (Blick, 1979).

In summary: (1) the Mineral Fork Formation may have been deposited wholly below sea level, and marked tectonic subsidence is neither required nor likely; (2) throughout the formation, rafting was probably less important than debris flow and lodgement mechanisms for sediment emplacement; and (3) in my opinion, the proposed contact between "lower" and "upper" members does not correspond to any important change in sedimentary processes or environment.

\section{ACKNOWLEDGMENTS}

Julia M. G. Miller, Paul K. Link and John C. Crowell made numerous helpful comments on an earlier draft of this discussion.

\section{REFERENCES CITED}

stituting $70 \%$ to $75 \%$ of the formation, were dominantly deposited from floating ice, more contacts would be expected to be gradational. It is possible that the diamictite could have been rafted prior to resedimentation by debris flow, although it seems just as likely that it originated from grounded ice.

In addition, massive diamictite overlying
Blick, N. H., 1979, Stratigraphic, structural and paleogeographic interpretation of upper Proterozoic glaciogenic rocks in the Sevier orogenic belt, northwestern Utah [Ph.D. dissert.]: Santa Barbara, California, University of California, $633 \mathrm{p}$.

Christie-Blick, N., 1980, Glacial advance and retreat sequences, upper Proterozoic Min- 
eral Fork Formation, northwestern Utah: Geological Society of America Abstracts with Programs, v. 12, no. 6, p. 269.

Crittenden, M. D., Jr., Schaeffer, F. E., Trimble, D. E., and Woodward, L. A., 1971, Nomenclature and correlation of some upper Precambrian and basal Cambrian sequences in western Utah and southeastern Idaho: Geological Society of America Bulletin, v. 82, p. $581-602$.

Denton, G. H., Armstrong, R. L., and Stuiver, M., 1971, The late Cenozoic glacial history of Antarctica, in Turekian, K. K., ed, Late Cenozoic glacial ages: New Haven, Connecticut, Yale University Press, p. 267-306.

Ojakangas, R. W., and Matsch, C. L., 1980 , Upper Precambrian (Eocambrian) Mineral Fork Tillite of Utah: A continental glacial glaciomarine sequence: Geological Society of America Bulletin, Part I, v. 91, p. 495-501.

Rust, B. R., and Romanelli, R., 1975, Late Quaternary subaqueous outwash deposits near Ottawa, Canada, in Jopling, A. V., and
McDonald, B. C., Glaciofluvial and glaciolacustrine sedimentation: Society of Economic Paleontologists and Mineralogists Special Publication no. 23, p. 177-192.

Manuscript Received by the Society NOVEMBER 6, 1980 Manuscript ACCePted August 26, 1981

\section{Reply}

\section{RICHARD W. OJAKANGAS CHARLES L. MATSCH}

We welcome Christie-Blick's comments, for they may serve to generate further interest in the excellent exposures of diamictite in the Big Cottonwood Canyon area of the Wasatch Range, exposures which may be among the best preserved late Proterozoic (Eocambrian) diamictites anywhere. Basically, he concurs with our major interpretation that the Mineral Fork Tillite is indeed of glacial origin, but his interpretation differs from ours in some important aspects.

One point of conflict pertains to our striated basal contact. We certainly agree that in order to demonstrate that lineations are the result of late Proterozoic glacial action, they must be truly surficial to the ancient bed-rock surface, and other mechanisms that produce lineations, such as faulting of Pleistocene glaciers, must be objectively eliminated. Keeping these criteria in mind now, as we did in 1976 and again in 1980 because we are firm believers in multiple working hypotheses, we re-emphasize that the striations, grooves, and polish which we have observed on the upper surface of the Big Cottonwood Quartzite at several places (Christie-Blick's italics) along $1.5 \mathrm{~km}$ of contact in the vicinity of Lake Blanche in Mill B South Fork Canyon are indeed the result of late Proterozoic glaciation. We observed no faults or slickensides along the contact here. Lineations on the contact disappear into the cliff face and cannot in any way be attributed to action by Pleistocene glaciers which would, at any rate, have moved down the valley along a trend of about $330^{\circ}$. A total of 14 "lineations" (our striations and grooves) along the contact show a strong east-west trend. The average of 13 measurements which range from $235^{\circ}$ to $325^{\circ}$, is $268^{\circ}$ or $88^{\circ}$, and whalebacks (roche moutonnées) indicate that the correct sense of ice movement was westerly. A somewhat anomalous reading of $10^{\circ}$ is on a polished surface with two sets of striations at nearly right angles. All readings were corrected in the field for tectonic tilt.

Christie-Blick states that the very presence of a polished surface makes the striations on that surface suspect because polish is lack- ing at most exposures of the unconformity. We strongly disagree, for would not Holocene-Recent weathering degrade an exposed ancient polished surface just as it would an exposed Pleistocene polished surface? Do remnants of polish on a surface striated during the Pleistocene make the striations or grooves any less convincing? Finally, are not whalebacks on a surface as shown in our Figure 6 and as found by Christie-Blick (locality 1 on his Fig. 1) unequivocal evidence of a glaciated surface? Unfortunately, the polish and very delicate striations are difficult to reproduce in a printed photograph, and so we cannot portray their nature. We are delighted that Christie-Blick found grooves at his locality 1 which he accepts as being of Proterozoic glacial origin.

We agree with Christie-Blick that the lower part of the sequence could have been deposited from a marine-based grounded glacier rather than from a glacier whose base was above sea level of the time. If that were the case, the stratigraphic succession of diamictites interbedded with shales, sandstones, and conglomerates would indicate repeated fluctuation of the grounding line. The only Quaternary sediments we have seen that were deposited under such conditions, and therefore can serve as analogues, are exposed in eastern Maine, below the marine limit. There, successive positions of the grounding line are marked by arcuate moraines characteristically comprised of diamictons, outwash, and fossiliferous marine silt and clay interbedded on a scale of centimetres to a few metres. In places, the bedding is deformed into overturned folds and thrust faults produced by ice push. In total, the Mineral Fork Tillite does not display the ensemble of features expected at or near a grounding line, weakening the case for a grounded-ice environment of deposition. The sedimentary details in the lower part of the sequence described in our paper are better interpreted as being the result of land-based glaciation.

Christie-Blick interprets the thickness of the Mineral Fork as being controlled more by a submerged pre-existing topography 
than by tectonic subsidence. Surely a submerged topography would wield some control over the thickness of grounded glacier deposits, but probably not of primary ice-rafted material. We feel the preservation of a $900 \mathrm{~m} \Leftrightarrow$ thickness of sediment, mostly diamictite, would have been enhanced by tectonic subsidence during sedimentation. Surely the location of the depocenter of the Mineral Fork Tillite along the continental margin makes subsidence likely.

Christie-Blick questions our interpretation that the upper diamictites were deposited from floating ice; he interprets them as flow or lodgement tills, apparently because of the lack of gradational contacts between the diamictites and underlying shale-siltstone units. His flow or lodgement till origin, without internal stone orientations as evidence to support such an origin, is no less interpretive than our explanation (1980) of fluctuating rates of ice rafting. The stratigraphic context, we continue to believe, is strongly suggestive of a subaqueous origin rather than a subglacial one. We are now processing oriented samples of diamictite which may shed further light on their origin.

We postulated the orthoconglomerate pods which occur at the top of a shale unit and which are directly overlain by diamictite to be ice tunnel deposits formed within a marine-based grounded glacier. Christie-Blick notes that the overlying diamictite could have thus been deposited by grounded ice. We agree, but it is just as likely that the tunnels could have been formed in grounded bergs.

Again disagreeing with Christie-Blick, we maintain that the lithologic distinctions between the "upper" and "lower" members are quite distinct because of the relative abundances of certain litholo- gies. Admittedly, most lithologies occur in both members, as shown clearly in our Figure 3 (1980). However, thick, concretion-bearing shale units with graded beds (our Fig. 12) occur mainly in the upper member, and fissile ("shaley") diamictites (our Fig. 11) occur only in the upper member. In our opinion, these differences correspond to a transition from glacial deposition to glacio-marine deposition and a change from a continental or nearshore environment to a more distal marine environment.

In summary, we believe that the Mineral Fork Tillite affords a rare view of two complex sedimentary environments, continental glacial and glaciomarine. This and other ancient diamictites of similar origin are valuable records of past glacial activity and extent, and in the case of glaciomarine deposits, they give to sedimentologists an opportunity to study in detail the results of geological processes not easily accessible in the modern environment.

\section{REFERENCES CITED}

Ojakangas, R. W., and Matsch, C. L., 1976, The upper Precambrian Mineral Fork Tillite, Utah: A glacial and glaciomarine sequence: Geological Society of America Abstracts with Programs, v. 8., p. 1035.

1980, Upper Precambrian (Eocambrian) Mineral Fork Tillite of Utah: A continental glacial and glaciomarine sequence: Geological Society of America Bulletin, Part 1, v. 91, p. 495-501.

Manuscript Received by the Society August 19, 1981

MANUSCRIPT ACCEPTED AUGUST 26, 1981 